NBER WORKING PAPER SERIES

\title{
SOCIAL SECURITY AND THE TIMING OF DIVORCE
}

\author{
Gopi Shah Goda \\ John B. Shoven \\ Sita Nataraj Slavov \\ Working Paper 13382 \\ http://www.nber.org/papers/w13382
}

\author{
NATIONAL BUREAU OF ECONOMIC RESEARCH \\ 1050 Massachusetts Avenue \\ Cambridge, MA 02138 \\ September 2007
}

This research was supported by the U.S. Social Security Administration through grant \#10-P-98363-1-04 to the National Bureau of Economic Research as part of the SSA Retirement Research Consortium. The opinions and conclusions expressed are solely those of the authors and do not represent the opinions or policy of SSA, the National Bureau of Economic Research, or any agency of the Federal Government. The authors would like to thank Justin Wong for superb research assistance.

(C) 2007 by Gopi Shah Goda, John B. Shoven, and Sita Nataraj Slavov. All rights reserved. Short sections of text, not to exceed two paragraphs, may be quoted without explicit permission provided that full credit, including $(\subset$ notice, is given to the source. 
Social Security and the Timing of Divorce

Gopi Shah Goda, John B. Shoven, and Sita Nataraj Slavov

NBER Working Paper No. 13382

September 2007

JEL No. H55,J12

\begin{abstract}
$\underline{\text { ABSTRACT }}$
Social Security provides spousal benefits in retirement to secondary workers in married couples based on the primary worker's earnings record. In addition, Social Security pays spousal benefits to divorced secondary workers whose marriages lasted at least ten years. However, if a marriage failed in less than ten years, no spousal benefits are paid. The spousal benefit is particularly valuable to secondary workers in couples where there is a large disparity in earnings between the primary worker and the secondary worker. We examine whether these couples, who have more to gain from extending their marriage to ten years, are more likely to delay divorce to the tenth year relative to a control group. We find that vulnerable couples are slightly more likely to delay divorce from year nine to year ten; however, the effect is statistically insignificant and small in magnitude. While the "cliff"-vesting of retirement benefits for divorced spouses raises equity concerns, it does not appear to distort incentives for divorce.
\end{abstract}

Gopi Shah Goda

Robert Wood Johnson Scholars

in Health Policy Research Program

Harvard University

1730 Cambridge Street

Cambridge, MA 02138

gopi.shah.goda@gmail.com

John B. Shoven

NBER

30 Alta Road

Stanford, CA 94305-8715

and NBER

shoven@leland.stanford.edu
Sita Nataraj Slavov

Dept. of Economics

Occidental College

1600 Campus Road

Los Angeles, CA 90041

sslavov@oxy.edu 


\section{Social Security and the Timing of Divorce \\ Gopi Shah Goda, John B. Shoven, and Sita Nataraj Slavov}

\section{Introduction}

The Social Security system contains many features designed to provide an adequate retirement income for families, rather than just individual retired workers. The most important of these features is the spousal benefit, under which secondary earners are entitled to receive a monthly payment of 50 percent of their spouse's monthly Social Security benefit. Secondary earners may also elect to receive benefits based on their own earnings records if they are higher than the spousal benefit; historically, however, the spousal benefit provided a large source of benefits for non-working spouses in one-earner couples. Of course, the existence of a spousal benefit raises the questions about what happens in the event of divorce. Currently, an individual may not claim a spousal benefit based on an ex-spouse's earnings record if the marriage lasted less than 10 years. If the marriage lasted 10 years or more, however, the divorced spouse is entitled to the full spousal benefit in retirement.

The spousal benefit and the general rules for divorce were designed during the early years of the program, during which family structure differed considerably from today. At the inception of the system, such a design made sense. As discussed by Smith (2002), in 1940, almost three quarters of families had a working husband and non-working wife; less than 10 percent were two-earner couples. In contrast, in 1998, only 15 percent were one-earner couples, and close to 50 percent were two-earner couples. Moreover, women’s labor force participation has increased from around 34 percent in 1950 to 
almost 60 percent in 2005. ${ }^{1}$ As a result, more married women receive benefits based on their own records, making the spousal benefit (and divorce rules) irrelevant for a larger fraction of the population. The Social Security Administration reports that in 1970, 16 percent of benefit recipients were receiving spousal benefits; by 2005, this number had fallen to around 7 percent. This shift in family structure has led to a criticism of the spousal benefit on equity grounds, as one-earner couples receive a higher rate of return from Social Security compared to two-earner couples. The existence of the spousal benefit also has efficiency considerations from a labor supply point-of-view: secondary earners face large distortions in their labor supply decisions because their Social Security contributions only increase their benefits to the extent that they are larger than the spousal benefit (Feldstein and Samwick (1992), Goda (2007)).

Divorce rates have also increased considerably over the last half a century. The divorce rate has risen from about 2.6 divorces per year per 1,000 people in 1950, to 3.7 divorces per year per 1,000 people in $2004 .^{2}$ In 1950, only about 2 percent of men and women reported their marital status as divorced; by 2005, this number had risen to 11 percent for women and 9 percent for men. The increase in the divorce rate makes the divorce rules more relevant for individuals who plan to claim the spousal benefit. ${ }^{3}$

Social Security’s rules for divorce have also been criticized on equity grounds. A marriage lasting only 9 years leaves a non-working spouse with no benefit entitlement; on the other hand, staying together for 10 years results in a large increase in potential benefits. Thus, a shorter marriage may leave a divorced spouse with inadequate income

\footnotetext{
${ }^{1}$ Statistical Abstract of the United States, 2007, Table 575

${ }^{2}$ Statistical Abstract of the United States, 2007, Table 76.

${ }^{3}$ U.S. Census Bureau, Marital Status of the Population 15 Years Old and Over, by Sex and Race: 1950 to Present, Table MS-1.
} 
in retirement. As reported by Smith (2002), in 1990, the median marriage length among divorced couples was only 7.2 years, with 63 percent divorcing within 10 years.

Therefore, the 10-year requirement potentially affects a large number of individuals.

Favreault et al. (2006) provide a detailed analysis of the equity implications of the current system; they also evaluate a variety of reforms including income splitting, under which a couple's total earnings credits are split equally at the time of divorce.

In this paper, we focus on the efficiency implications of Social Security's divorce rules. One might expect these rules to affect the timing of divorce. For a couple married 9 years, there is a strong incentive to wait until the $10^{\text {th }}$ year to divorce. Moreover, a divorced person may be reluctant to remarry if it means giving up the spousal benefit from the first marriage. Of course, these incentives only apply to couples in which the secondary earner intends to claim spousal benefits, rather than benefits based on her own earnings record. Dickert-Conlin and Meghea's (2004) results - which are based on divorce rates aggregated by age of the wife - suggest that Social Security's rules do not appear to affect the timing of divorce and remarriage.

We revisit this question using the Panel Study of Income Dynamics (PSID) Marital History File. This dataset allows us to do an individual-level analysis, in which we control for characteristics, including the likelihood of claiming the spouse benefit. To do this, we identify "vulnerable" individuals, who are likely to claim spousal benefits instead of benefits based on their own records. Vulnerable individuals are likely to be affected by Social Security's divorce rules. Couples with a vulnerable spouse have an incentive to delay divorce from year 9 to year 10 in order to preserve the vulnerable spouse's Social Security benefit. There are no similar incentives for delay in the timing 
of divorce among couples in which both individuals intend to claim their own Social Security benefit.

Our household-level analysis corroborates the findings of Dickert-Conlin and Meghea. We find that vulnerable couples are slightly more likely than non-vulnerable ones to delay divorce from year 9 to year 10 . However, the difference is small and statistically insignificant. We attribute this finding to several possible factors. For example, the Social Security benefit computation is complex, and many individuals may not be aware of the divorce rules. In addition, there is plenty of evidence to suggest that individuals are myopic in planning for their retirements. Thus, it should not be surprising if young couples do not consider the implications of delaying divorce for their future Social Security benefits.

This paper is organized as follows. Section II provides an overview of Social Security’s rules regarding marriage and divorce, and a review of the previous literature. Section III presents our methodology and results. Section IV concludes.

\section{Background and Previous Literature}

Social Security provides a spousal benefit equal to 50 percent of the primary earner’s Primary Insurance Amount (PIA) to spouses of workers who have been married for at least one year. The PIA is determined by applying a concave function to the Average Indexed Monthly Earnings (AIME) which is the monthly average of the highest 35 years of the worker's wage-indexed earnings during their lifetime. The concavity in the formula provides low lifetime income earners with a higher replacement rate than high lifetime income earners. The secondary earner's benefit is the maximum of the spousal 
benefit and the benefits determined by his or her own earnings record. Because of the progressivity of the formula that converts the AIME to a PIA, it is not the case that workers need to earn, on average, 50 percent of what the primary worker earns every year in order to generate a benefit larger than the spousal benefit. The exact fraction depends on the relative earnings amounts within the couple, but in many instances is closer to onethird. Figure 1 shows the necessary fraction of the primary worker's earnings for different values of the primary worker’s average indexed monthly earnings.

\section{Figure 1}

\section{Percent of Primary Worker's AIME Needed to Earn More Than Spousal Benefit}

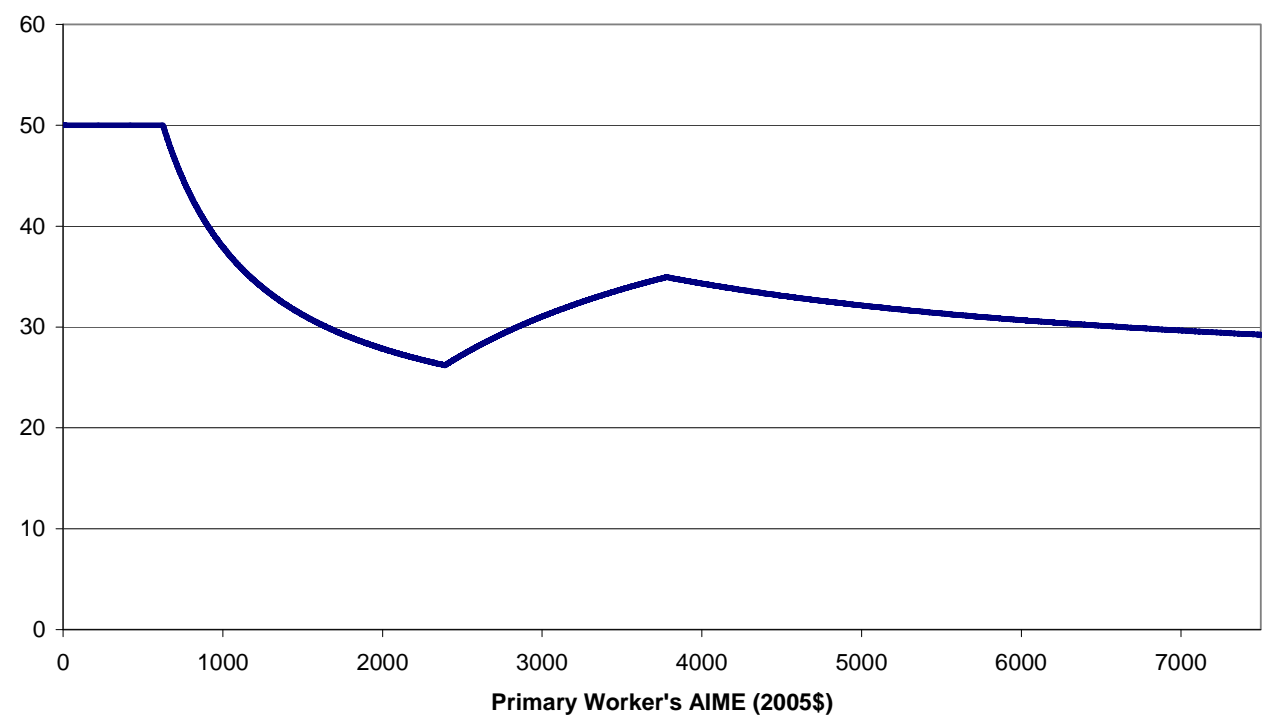

According to the Social Security Administration, there were almost 31 million workers receiving benefits based on their own earnings record in 2006. In addition to this, around 2.5 million individuals received spousal benefits. Of those receiving spousal benefits, more than 98 percent were female. However, women are increasingly likely to receive benefits based on their own earnings record. In 1970, around 2.7 million women 
received spousal benefits. By 2006, that had fallen to 2.4 million despite an increase in the elderly female population. ${ }^{4}$

When a couple divorces, the secondary earner is entitled to collect the full Social Security spousal benefit if the marriage lasted 10 or more years. However, if the secondary earner remarries, the spousal benefit from the first marriage is no longer available. (It is, therefore, possible for several individuals to receive spousal benefits for the same primary worker.) The 10-year requirement is relatively recent. Prior to 1977, a marriage was required to last for 20 years before an ex-spouse could claim the spousal benefit. Increasing divorce rates in the 1960s and 1970s prompted the change in the law, as policy makers were concerned that women who were divorced after less than 20 years of marriage would be left in poverty.

Dickert-Conlin and Meghea (2006) carry out a differences-in-differences analysis that focuses on the 1977 law change. They compare the divorce rates of 7-year marriages (the control group) with those of 9- and 10-year marriages (the treatment groups) both before and after 1977. One would expect the divorce rate in the 9-year marriage group to fall relative to the control group after 1977, as postponing divorce by a year would result in an entitlement to a spousal benefit. (In contrast, the 7-year marriage group would have to postpone divorce by three years, which has a significantly higher cost.) Additionally, the 10-year marriage group should have displayed an increase in divorces relative to the control group after 1977. The authors find some evidence of a decline in the divorce rate for 9-year marriages; however, there appears to have been no impact on 10-year marriages. Hence there is not much support for the claim that the change in Social Security’s divorce rules affected the timing of divorce. A similar analysis suggests that

\footnotetext{
${ }^{4}$ Social Security Administration, Social Security Beneficiary Statistics, December 20, 2006.
} 
remarriage behavior was not affected either. In this case, the treatment group is women whose marriages lasted for 10 years. This group of women became eligible for spousal benefits in 1977, provided they did not remarry. The control group is women whose marriages lasted for 9 years, and were therefore not eligible for spousal benefits. One would expect the latter group to have a higher remarriage rate than the former after the 1977 law change; however, the data did not support this claim.

Of course, the predicted effect on behavior only apply to couples in which the secondary earner intends to claim spousal benefits, rather than benefits based on her own earnings record. The Dickert-Conlin and Meghea (2006) analysis makes no distinction between these two groups. This provides a possible alternative explanation for their findings. If many women are claiming benefits on their own record, then one might not find an effect for women overall, as only a subset of women alter their behavior.

While the existing literature provides little evidence of distorted behavior, the divorce rules certainly raise significant equity concerns. The current method of 10-year “cliff”vesting means that secondary workers with marriages that lasted 9 years and 11 months will not receive any spousal benefits from Social Security from that marriage, while those in marriages lasting 10 years would receive spousal benefits based on their ex-spouse's entire earnings history at retirement. Favreault and Steuerle (2006) point out that, while the overall poverty rate among the elderly is low, poverty is significant problem among elderly women. The policy also creates large disparities in taxes paid relative to benefits received. For example, a man who marries multiple times for 10 years or longer can obtain (for his exes) several spousal benefits from one earnings history. 
As discussed by Thompson and Carasso (2002), many other countries use earnings sharing to address such equity concerns. In Belgium and France, for example, divorced spouses receive a benefit that is tied to the length of the marriage. Many other industrialized countries split the couple's total earnings credits at the time of divorce, treating the divorced couple as two singles in computing benefits. The earnings-splitting is either specified by law (e.g. in Canada, Germany, and Switzerland), or determined by the divorce court (e.g., in Spain and the United Kingdom).

Favreault and Steuerle (2006) investigate the implications of several reforms that aim to improve the equity, efficiency, and adequacy of Social Security's treatment of the family. They examine three versions of earnings-splitting proposals, and incremental changes such as providing a minimum level of benefits and providing caregiver credits. The simulated winners and losers under each proposal differ, but divorced women fare better under earnings-splitting reforms.

Brien et al. (2001) study another aspect of the Social Security system: the treatment of widows. When a widow reaches normal retirement age, she may claim a widow benefit equal to 100 percent of her deceased husband's PIA. Prior to 1979, a widow who remarried lost her claim on the widow benefit, although she could claim a spousal benefit based on the earnings of her new husband. The spousal benefit is, of course, less generous than the widow benefit, as it amounts to only 50 percent of the primary earner's PIA. In 1979, the law was changed to allow widows aged 60 and above to claim the widow benefit even if they remarried. However, widows under age 60 were still subject to the old rules. The authors show that widows aged 60 and above had an increased marriage rate in 1979, indicating that many individuals in this group had waited to 
remarry until the law went into effect (it was passed in 1977). Moreover, they found that after 1979, marriage rates declined among widows just under age 60, and increased among widows over 60 . This indicates that after 1979, widows just under age 60 started waiting until age 60 to remarry in order to retain their widow benefit.

Our analysis also fits into the broader literature on how fiscal policy affects individuals' choice of family structure. A number of studies have shown that marriage penalties created by the income tax and welfare programs have an impact on the timing of marriage and divorce. Alm et al. (1999) provide a review of this literature.

\section{Data and Methodology}

Our data come from the Panel Study of Income Dynamics (PSID) 1985-2003 Marital History File. This dataset contains a marital history for each PSID respondent. Since respondents are asked to provide information about previous marriages, the histories also include marriages that began and ended prior to 1985. For our analysis, each observation consists of one marriage for an individual in the survey. If an individual has multiple marriages, it is possible for that person to appear in multiple observations. However, because of the data collection procedures, not all marriages for all individuals appear in the data. We generally treat each marriage as a separate observation. Clearly, multiple marriages for the same individual might not be independent observations. To see if this affects the results, we also do all of our estimates using only the first marriage that appears in the sample for all individuals. Our qualitative results do not change. ${ }^{5}$ After dropping observations with missing values, we end up with a sample of 16,361

\footnotetext{
${ }^{5}$ These results are available from the authors upon request.
} 
marriages. We merge this marital history data with the income data routinely collected by the PSID.

According to our discussion in the previous section, an individual whose AIME is less than a third of his or her spouse's is better off claiming the spouse benefit. We define an individual as defined "vulnerable” if his or her average is less than a third of the primary worker's income. Vulnerable individuals are most likely to rely on the spousal benefit, rather than benefits based on their own records. Couples with a vulnerable spouse are most likely to alter their behavior in response to Social Security’s divorce rules. Of course, the calculation of the spousal benefit is based on the individuals' AIMEs, which take into account their wages over their entire working life. During the earlier years of a marriage, individuals cannot know with certainty their ultimate AIME. At this point, a couple's expected AIMEs will influence the divorce decision. Of course, estimating an individual's expected average income is tricky. For our base case, we average income in all years prior to and during the marriage for which data are available. This computation contains two implicit assumptions. First, the couple perfectly anticipates their future income path during the marriage. Second, for marriages that end in divorce, the individuals’ average incomes up until the divorce decision are a good estimate of what their average incomes would have been had the marriage continued. Note that we do not include years after the marriage ended. An individual may intend to claim the spousal benefit while married, yet seek out a higher paying job if the marriage ends. Such an individual should correctly be classified as vulnerable, as it is their anticipated status during the marriage that is relevant for the divorce decision. 
By this definition, there are 6,883 marriages in which one spouse is vulnerable. In 91.1 percent of these marriages, the vulnerable spouse is the wife. Clearly our definition of vulnerable individuals does not perfectly capture those who intend to receive spousal benefits. However, there should be a correlation between vulnerability as defined here and the dependence on spousal benefits.

Vulnerable marriages are our treatment group for the analysis. The control group consists of all the other marriages. We predict that the treatment group should be more responsive to Social Security's divorce rules than the control group. Consider the set of all couples entering their $9^{\text {th }}$ year of marriage who are contemplating divorce. Those in the treatment group have larger costs associated with divorce before 10 years. Therefore, we would expect a decline in the divorce rate of the treatment group, relative to the control group, at 9 years of marriage. We would also expect an increase in the relative divorce rate of the treatment group at 10 years of marriage.

Figure 2 depicts the conditional and unconditional probabilities of divorce by length of marriage for the entire sample. The probability of divorce is simply the fraction of marriages ending after $t$ years. The conditional probability of divorce is the fraction of couples divorcing after $t$ years of marriage, conditional on being married at time $t-1$. (The graph does not include the 316 marriages that either failed or left the sample before the first year.) Only about 1 percent of marriages fail after one year. The divorce rate increases until the $4^{\text {th }}$ year of marriage, then levels off and falls. 
Figure 2

Conditional and Unconditional Probability of Divorce for All Individuals

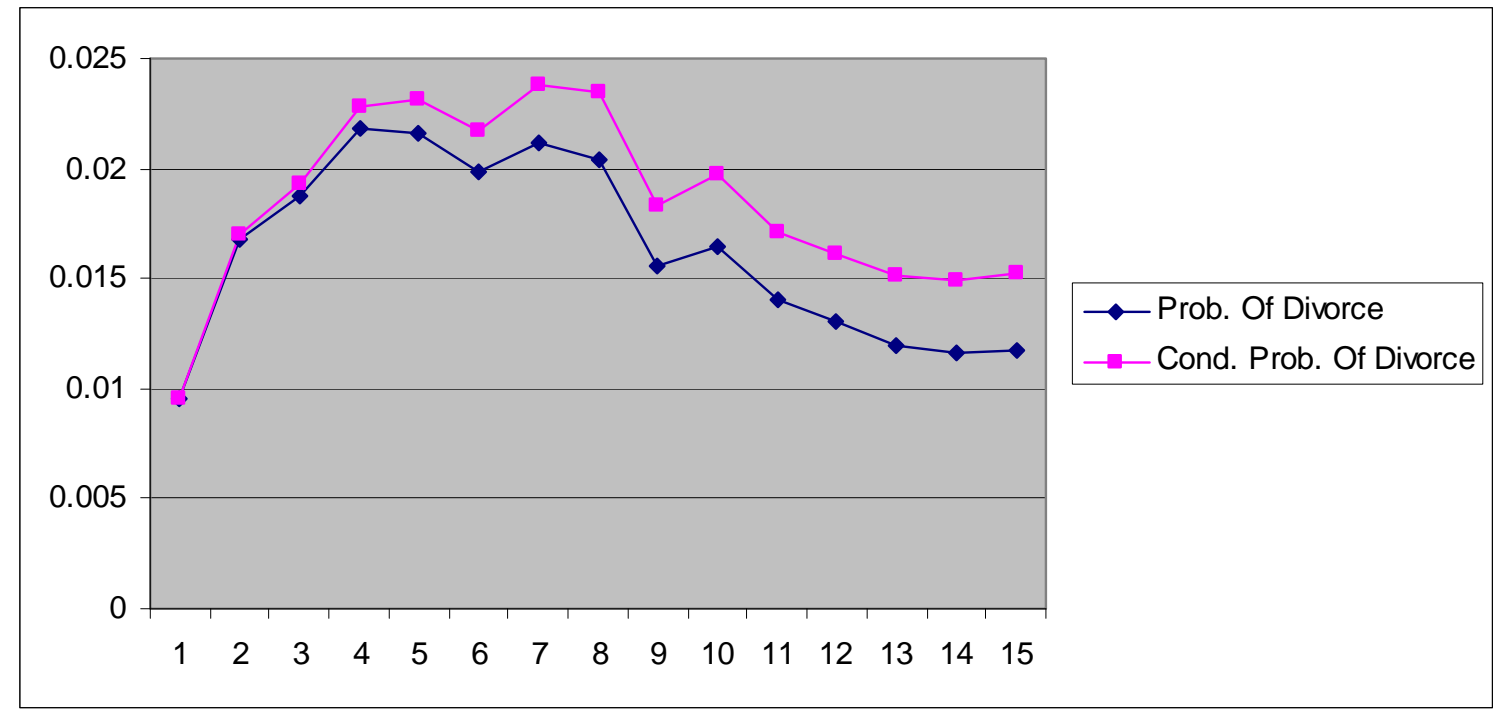

Figure 3 shows the conditional divorce probability for the vulnerable group and the entire sample. There appears to be a small dip in the probability of divorce in year 9, followed by an increase in year 10. However, this appears for both the control and the treatment groups. Moreover, for both groups, the effect appears to be small.

Figure 3

\section{Conditional Probability of Divorce: Control Group, Treatment Group, Full Sample}

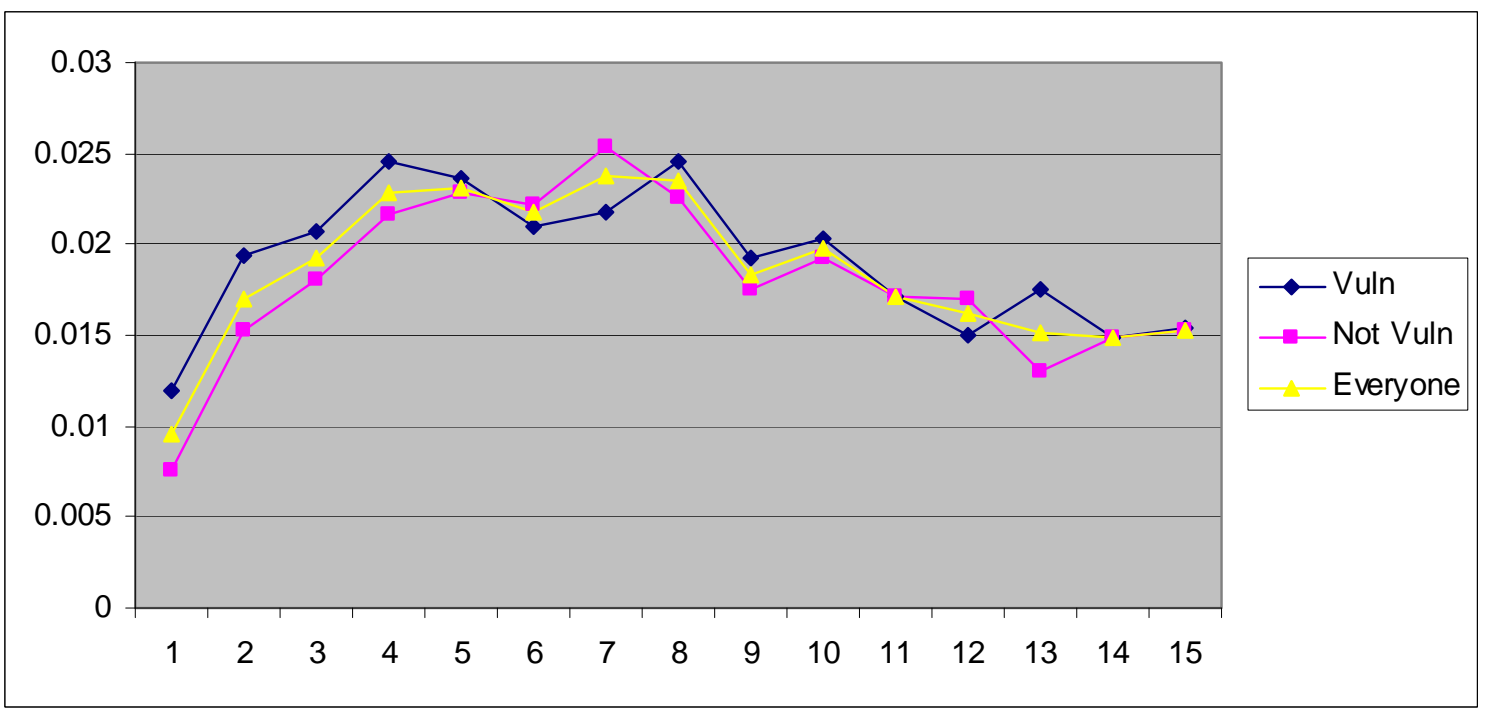


We perform a formal regression analysis to determine whether there is any statistically significant impact of Social Security's divorce rules. We begin with the set of all marriages lasting 8 or more years. There are three possible outcomes for these 8year marriages:

1. Divorce in year 9 ,

2. Divorce in year 10 , or

3. No divorce in either year 9 or year 10 .

We estimate the following multinomial logit model:

$$
p_{i j}=\frac{\exp \left(\beta_{j} X_{i}+\alpha_{j} T_{i}\right)}{\sum_{j=1}^{3} \exp \left(\beta_{j} X_{i}+\alpha_{j} T_{i}\right)}
$$

Here, $p_{i j}$ is the probability that marriage $i$ ends in outcome $j$, for the $j=1,2,3$ specified above. $T_{i}$ is a dummy variable equal to 1 if marriage $i$ is in the treatment group (has an always-vulnerable spouse). $\quad X_{i}$ is a vector of controls for the couple, including dummies for the race of the household head, ${ }^{6}$ whether each spouse was over the age of 22 at the beginning of the marriage, and whether each spouse had finished high school and college prior to the end of the marriage. The PSID's racial classifications have expanded greatly over time. In the initial years of the survey, the only categories coded were white, African-American, and other race. Therefore, we consolidate the racial categories in subsequent waves of the survey and include only indicators for African-American and other race. The entire sample of 8-year marriages consists of 8,474 observations, of which 3,877 have a vulnerable spouse. Including the independent variables reduces the sample size to 8,076, as we are forced to drop observations with missing values.

\footnotetext{
${ }^{6}$ Race is only available for the household head.
} 
Table 1 presents the means and standard deviations for the independent variables broken down by vulnerability status. The control groups have similar marriage lengths. Both husbands and wives in the treatment group tend to get married at a younger age: 71 percent of men in the treatment group were over the age of 22 at marriage, compared to 78 percent in the control group. For the wives, 55 percent of the treatment group was over 22 at the time of marriage, compared to 64 percent of the control group.

Table 1: Summary Statistics

\begin{tabular}{|c|c|c|c|c|c|c|}
\hline Variable & \multicolumn{2}{|c|}{ Full Sample } & \multicolumn{2}{c|}{ Vulnerable } & \multicolumn{2}{c|}{ Not Vulnerable } \\
\hline & Mean & Std. Dev. & Mean & Std. Dev. & Mean & Std. Dev. \\
\hline $\begin{array}{c}\text { Length of } \\
\text { Marriage }\end{array}$ & 18.26 & 7.15 & 18.81 & 7.33 & 17.80 & 6.97 \\
\hline $\begin{array}{c}\text { Husband } \\
\text { Over 22 at } \\
\text { Marriage }\end{array}$ & 0.75 & 0.43 & 0.71 & 0.46 & 0.78 & 0.41 \\
\hline $\begin{array}{c}\text { Wife Over } \\
\text { 22 at } \\
\text { Marriage }\end{array}$ & 0.60 & 0.49 & 0.55 & 0.50 & 0.64 & 0.48 \\
\hline $\begin{array}{c}\text { Husband } \\
\text { Finished } \\
\text { College }\end{array}$ & 0.25 & 0.43 & 0.25 & 0.43 & 0.25 & 0.43 \\
\hline $\begin{array}{c}\text { Husband } \\
\text { Finished } \\
\text { High } \\
\text { School }\end{array}$ & 0.60 & 0.49 & 0.58 & 0.49 & 0.63 & 0.48 \\
\hline $\begin{array}{c}\text { Wife } \\
\text { Finished } \\
\text { College }\end{array}$ & 0.21 & 0.41 & 0.16 & 0.36 & 0.25 & 0.44 \\
\hline $\begin{array}{c}\text { Wife } \\
\text { Finished } \\
\text { High } \\
\text { School }\end{array}$ & 0.67 & 0.47 & 0.67 & 0.47 & 0.67 & 0.47 \\
\hline $\begin{array}{c}\text { Head } \\
\text { African } \\
\text { American }\end{array}$ & 0.28 & 0.45 & 0.21 & 0.41 & 0.33 & 0.47 \\
\hline $\begin{array}{c}\text { Head Other } \\
\text { Race }\end{array}$ & 0.06 & 0.23 & 0.07 & 0.25 & 0.05 & 0.22 \\
\hline
\end{tabular}


Wives in the control group are more likely to have finished college (but not high school). Husbands in the control group are more likely to have finished high school (but not college). Finally, the control group contains a greater percentage of African American household heads.

Relative risk ratios for outcome 2 (divorce in year 10) relative to outcome 1 (divorce in year 9) are presented in Table 2. ${ }^{7}$ The first column of Table 2 uses a vulnerability definition that incorporates income throughout the length of the marriage. The coefficient of interest is the relative risk ratio for the treatment dummy, which indicates the treatment group's risk of getting divorced in year 10 relative to $9\left(p_{i 2} / p_{i 1}\right)$, divided by the same ratio for the control group. Our prediction is that this value should be greater than 1 - that is, relative to the control group, the treatment group's probability of divorce falls in year 9 and increases in year 10. The point estimate of the relative risk ratio is 1.12, suggesting that the treatment group is slightly more likely than the control group to delay divorce from year 9 to year 10 . However, this coefficient is statistically insignificant. In general, the other independent variables don't appear to be statistically significant either.

As discussed above, our definition of vulnerability assumes that couples perfectly anticipate their future income path if the marriage continues. As a robustness check, we redo our regression analysis under the alternative that couples do not anticipate any future changes in their income. That is, we classify people as vulnerable if their average income until the $8^{\text {th }}$ year of marriage is less than a third of their spouse's. The implicit assumption here is that individuals expect their future average income to be similar to

\footnotetext{
${ }^{7}$ Relative risk ratios for the never divorced outcome relative to outcome 1 are omitted, but are available from the authors upon request.
} 
their average income in the $8^{\text {th }}$ year of marriage. The sample size for this case is only 7,517, as we must drop marriages in which both spouse's average earnings are zero, which are more likely to occur when we only compute average earnings until the $8^{\text {th }}$ year of marriage. Regression results for this case are given in the second column of Table 2. They are qualitatively similar to the base case. The treatment group's relative probability of divorce does fall in year 9 and rise in year 10 . However, this difference is statistically insignificant.

The only independent variable that is statistically significant in both regressions is the dummy variable for the wife's age at the time of marriage. The relative risk ratio is less than 1 , indicating that a woman who is younger when she marries is relatively more likely to delay divorce until year 10. This is roughly consistent with the hypothesis that vulnerable couples delay divorce: a woman who married at a young age is more likely to be vulnerable (in a way that is not captured by our vulnerability measure) and therefore more likely to anticipate receiving the spouse benefit. However, given the insignificance of our direct measure of vulnerability, we hesitate to interpret this isolated finding as evidence that Social Security’s divorce rules affect behavior. 
Table 2: Regression Results

\begin{tabular}{|c|c|c|}
\hline $\begin{array}{c}\text { Dependent } \\
\text { variable }\end{array}$ & Base Case & $\begin{array}{c}\text { Average Income } \\
\text { Through Year 8 Only }\end{array}$ \\
\hline Treatment Group & 1.12 & 1.10 \\
& $(0.14)$ & $(0.14)$ \\
\hline Head African- & 1.16 & 1.15 \\
American & $(0.15)$ & $(0.15)$ \\
\hline Head Other Race & 1.71 & 1.61 \\
& $(0.57)$ & $(0.54)$ \\
\hline Husband Over 22 & 1.11 & 1.12 \\
at Marriage & $(0.20)$ & $(0.20)$ \\
\hline Wife Over 22 at & $0.69 *$ & $0.68^{*}$ \\
Marriage & $(0.11)$ & $(0.11)$ \\
\hline Husband Finished & 0.75 & 0.76 \\
High School & $(0.14)$ & $(0.14)$ \\
\hline Husband Finished & 0.85 & 0.88 \\
College & $(0.20)$ & $(0.20)$ \\
\hline Wife Finished & 1.10 & 1.05 \\
High School & $(0.24)$ & $(0.22)$ \\
\hline Wife Finished & 1.44 & $(0.35)$ \\
College & $(0.38)$ & . \\
\hline
\end{tabular}

* Significantly different from 1 at the 5 percent level. (Standard errors in parentheses.)

\section{Conclusion}

Social Security’s current rules regarding divorce allow secondary workers in marriages that lasted at least ten years to receive spousal benefits based on the primary worker's earnings history. However, secondary workers whose marriages lasted less than ten years do not receive this benefit. As a large number of marriages that fail do so before ten years, the rules create equity concerns. This “cliff”-vesting means that secondary workers in marriages that fail before ten years undergo a significant loss in terms of future retirement benefits, especially if their earnings were significantly lower than their spouses. In our sample of marriages that lasted at least eight years and using a definition of vulnerable that requires the secondary earner's average earnings to be at 
least one third of his or her spouse's average earnings, 46 percent of couples have a vulnerable spouse. This represents a significant percentage of all marriages.

We attempt to detect a behavioral response by spouses that are more vulnerable to a divorce before the tenth year of marriage relative to a control group. The control group consists of couples where the secondary earner would likely earn more than the spousal benefit. Because the secondary worker receives the maximum of the benefit calculated from his or her own earnings record and the spousal benefit, the spousal benefit is thought to be of little value to the secondary workers in the control group. While the presence of the spousal benefit still provides secondary workers in this category some insurance, it is relatively far less important to secondary workers in the control group relative to the vulnerable couples.

Our regression results show little evidence for a behavioral response among vulnerable couples relative to the control group. While the relative risk ratios in the multinomial regression indicate that vulnerable couples are slightly more likely to delay divorce in their ninth year of marriage to the tenth year, the effect is not statistically significant and is small in magnitude. Therefore, we conclude that the divorce rules in Social Security do not have strong efficiency implications with regards to divorce incentives even for couples where the secondary spouse is more vulnerable to the potential loss in retirement benefits. There are several possible explanations for why individuals may not respond to the incentives to delay divorce until the tenth year of marriage: individuals may not be fully aware of the divorce rules in Social Security; they may be myopic regarding the extra retirement benefits they are losing from earlier divorce; they may value the earlier dissolution of their marriage more highly than the 
added retirement benefits far into the future; they may have better information about their future earnings potential than is available in our data; or they may expect to remarry and receive spousal benefits from their future spouse's earnings record. Further research could shed some light on which of these explanations accounts for the insignificant behavioral response to divorce rules in Social Security. 
References:

Alm, James, Stacy Dickert-Conlin, and Leslie A. Whittington, "Policy Watch: The Marriage Penalty,” The Journal of Economic Perspectives, Vol. 13, No. 3. (Summer, 1999), pp. 193-204.

Brien, Michael J., Stacy Dickert-Conlin, and David A. Weaver, "Widows Waiting to Wed? Remarriage and Economic Incentives in Social Security Widow Benefits,” SSA Office of Research Evaluation and Statistics WP 89, January 2001.

Dickert-Conlin, Stacy and Cristian Meghea, “The Effect of Social Security on Divorce and Remarriage Behavior,” CRR WP 2004-09, April 2004.

Favreault, Melissa and Eugene Steurle, "Social Security Spouse and Survivor Benefits for the Modern Family, paper prepared for the annual Retirement Research Consortium conference, August 10-11, 2006.

Feldstein, Martin and Andrew Samwick, "Social Security Rules and Marginal Tax Rates,” National Tax Journal, Vol. 45, no. 1, pp. 1-22, March 1992.

Goda, Gopi Shah, “Implicit Social Security Tax Rates over the Life Cycle,” unpublished mimeo, April 2007.

Smith, Karen E., "The Status of the Retired Population, Now and in the Future," in Social Security and the Family, Melissa M. Favreault, Frank J. Sammartino, and C. Eugene Steurle, eds., Washington: Urban Institute Press, 2002, pp. 47-88.

Thompson, Lawrence H. and Adam Carasso, "Social Security and the Treatment of Families: How Does the United States Compare with Other Developed Countries?" in Social Security and the Family, Melissa M. Favreault, Frank J. Sammartino, and C. Eugene Steurle, eds., Washington: Urban Institute Press, 2002, pp. 123-176. 